\title{
Kesejahteraan Subjektif Perempuan Pemimpin Ditinjau dari Peran Optimisme dan Efikasi Diri
}

\author{
Nina Zulida Situmorang \\ Nina.situmorang@psy.uad.ac.id \\ Fakultas Psikologi Universitas Ahmad Dahlan
}

\begin{abstract}
This research aimed at examining the role of optimism and self efficacy to Kesejahteraan subjektifwomen leader. Eighty seven women leader of lecturer and Goverment employee at Yogyakarta were participated in this research.

The hypothesis was Kesejahteraan subjektifwomen leader can be predicted by optimism and self efficacy.

The multiple regression analysis was applied to analyze the correlation between the optimism and self efficacy as a single predictor and simultaneous predictors, and Kesejahteraan subjektifwomen leader. The result indicated there was possitive correlation between the predictors and criteria with $\mathrm{R}=0.577, \mathrm{p}<0.01$ ). The determinant coefficient $\mathrm{R}^{2}=33.30 \%$, so the effective contributions from the optimism and self efficacy Kesejahteraan subjektifwomen leader was $33.30 \%$.
\end{abstract}

Keywords: optimism, self efficacy, Subjective Wellbeing, women leader

\begin{abstract}
Abstrak
Penelitian ini bertujuan untuk menguji peran optimism dan efikasi diri terhadap Kesejahteraan subjektifperempuan pemimpin. Subjek terdiri dari 87 perempuan pemimpin di DI Yogyakarta.

Hipotesis yang diajukan dalam penelitian ini adalah Kesejahteraan subjektifperempuan pemimpin dapat diprediksi dari optimism dan efikasi diri.

Hasil analisis regresi ganda menunjukkan adanya korelasi positif antara optimism dan efikasi diri terhadap Kesejahteraan subjektifperempuan pemimpin. Sumbangan efektif variable Optimism dan efikasi diri Kesejahteraan subjektifperempuan pemimpin.adalah $\mathrm{R} 2=33.30 \%$, dengan demikian kontribusi optimism dan efikasi diri terhadap Kesejahteraan subjektifperempuan pemimpin sebesar $33.30 \%$.
\end{abstract}

Kata kunci: optimisme, efikasi diri, Subjective Wellbeing, perempuan pemimpin

\section{Pendahuluan}

Salah satu aspek penting untuk melihat kualitas hidup pekerja masa kini adalah faktor subjective well-being (SWB) dan kepuasan hidup (Diener \& Lucas, 2000). Faktor SWB yang dikenal dengan kebahagiaan adalah aspek penting yang menjadi tujuan hidup manusia yang melintasi usia, jenis kelamin, suku, bangsa dan agama. Manusia akan melakukan apapun untuk meningkatkan SWB. Hal ini terlihat semakin berkembang dari 
tahun ke tahun penelitian yang membahas SWB. Hal ini tidak terlepas dari peranan Seligman (2003) yang pertama kali mencanangkan psikologi positif sebagai arah dan orientasi baru dalam ilmu psikologi dengan SWB sebagai kajian utama. Penyebab rendahnya kesejahteraan subjektif umumnya adalah beban kerja, tekanan waktu, kualitas supervisi, dan perasaan tidak aman.

Perkembangan organisasi sekarang ini menghadapi banyak isu-isu strategik dan salah satunya adalah kualitas hidup kerja yang hanya dapat ditanggulangi melalui kapabilitas dan kearifan kolektif dari anggotanya. Organisasi yang mampu memenuhi semua kriteria ini memerlukan pemimpin efektif dan SWB yang tinggi diperoleh dengan adanya kepemimpinan efektif.

Jumlah perempuan yang menjadi pemimpin relatif kecil jika dibanding dengan pemimpin lakilaki. Bass (1990) menyatakan bahwa perempuan yang menjadi pemimpin mengalami persentase kenaikan yang cukup baik namun jika dibandingkan dengan populasi perempuan secara keseluruhan, persentase pemimpin perempuan jauh lebih rendah dibandingkan laki-laki. Untuk itu perempuan yang menjadi pemimpin membutuhkan SWB yang tinggi untuk meningkatkan kualitas pekerjaan dan diri dalam organisasi dan dalam keluarga.

\section{Latar belakang}

SWB diartikan bagaimana seseorang menilai kehidupan mereka baik saat ini dan tahun-tahun sebelumnya (Diener, Oishi, \& Lucas, 2003). Evaluasi ini mencakup reaksi emosional seseorang terhadap suatu kejadian, mood dan penilaian mereka terhadap kepuasan hidup, fulfillment dan kepuasan perkawinan dan kepuasan kerja. SWB tidak hanya menyangkut aspek emosi atau perasaan namun juga meliputi penilaian seseorang tentang hidupnya dan cenderung ke arah subjektif (Rakhmat, 2006).

SWB menjadi begitu penting karena dianggap tujuan akhir dari kehidupan. Orang yang bahagia memandang dunia lebih aman, membuat keputusan lebih mudah, menilai pelamar kerja lebih baik, lebih kooperatif, dan hidup lebih sehat, lebih enerjik, dan lebih memuaskan (Lyubomirsky, Kasri, \& Chang, 2002; Myers, 1993). Ketika bahagia, individu lebih suka membantu orang lain karena pengalaman yang membahagiakan seperti mendapat uang, berhasil menjalankan tugas yang menantang, mengenang saat bahagia membuat orang lebih besar kemungkinannya untuk memberikan sumbangan, 
mengorbankan waktunya dan sebagainya (Situmorang, 2012)

Penelitian menunjukkan adanya karakteristik dan sumber daya yang bernilai pada seseorang, berhubungan dengan kebahagiaan subjektif yang tinggi misalnya perkawinan (Mastekaasa, 1994), pendapatan yang tinggi (Diener \& Biswas-Diener, 2002), kesehatan mental (Koivumaa-Honkanen, Koskenvuo, Honkanen, Viinamaki, Heikkilae, \& Kaprio, 2004), dan usia tinggi (Danner, Snowdon, \& Friesen, 2001). . Beban menjadi semakin besar bagi perempuan yang menjadi pimpinan seperti yang dialami eksekutif dan profesional perempuan dalam organisasi dibanding hanya sebagai karyawan biasa. Para eksekutif perempuan cenderung memiliki tekanan darah yang tinggi setelah bekerja, mengalami gangguan mood dan tingkat kecemasan yang lebih tinggi dibandingkan lakilaki (Barette, 2006).

Review jurnal dan literatur menunjukkan bahwa faktor-faktor yang mempengaruhi SWB pada awal penelitian umumnya menitik beratkan pada faktor eksternal yaitu faktor demografi yakni kesehatan, pendapatan, latar belakang pendidikan dan status perkawinan dan hanya memberi sedikit sumbangan pada pengukuran kebahagiaan (Diener, 2002).

Veenhoven melakukan review 603 penelitian dari 69 negara menyimpulkan bahwa faktor demografi dan faktor lingkungan menunjukkan hasil yang berbeda namun faktorfaktor tersebut hanya memberi sedikit pengaruh dibandingkan faktor kepribadian. Selanjutnya penelitian berikutnya beralih pada faktor-faktor selain faktor eksternal yaitu faktor kepribadian.

Faktor kepribadian yakni rasa optimis menunjukkan hubungan dengan SWB. Menurut Diener (1999) orang-orang secara umum melaporkan hidup mereka lebih bahagia dan lebih puas memandang hidupnya adalah orang-orang yang lebih optimis. Individu yang optimis cenderung penuh harapan mengenai prospek, orang-orang, dan masa depan, bahkan terhadap kesukaran dan hambatan yang dirasakannya (Lounsbury, James, Eric, Lucy, Adam, \& Frances, 2003) .

Penelitian Lucas, Diener dan Suh (1996) menunjukkan bahwa optimisme berkorelasi dengan kebahagiaan subjektif seperti kepuasan hidup, afeksi menyenangkan dan tidak menyenangkan. Rasa optimis yang selalu terpelihara akan menunjukkan tingkat kebahagiaan subjektif tinggi pada saat menghadapi tekanan berdasar review yang dilakukan Scheier dan Carver (1993). Bukti-bukti tersebut menjadi dasar untuk menunjukkan terbentuknya mekanisme optimisme dimana orang optimis cenderung menyelesaikan masalah berdasar problem yang ada, mencari dukungan sosial, dan 
menekankan aspek fikiran positif pada saat menghadapi situasi sulit (Situmorang, 2012).

Faktor kepribadian lain yang menunjukkan pengaruh pada SWB adalah efikasi diri yang menjadi prediktor kepuasan hidup dan emosi positif (Feasel, 1995). Efikasi diri berhubungan dengan performance perempuan pemimpin (Judge, Thoreson, Bono, \& Patton, 2001). Bandura (1997) mendefenisikan efikasi diri sebagai keyakinan yang ada dalam diri seseorang terhadap kemampuan dirinya untuk mencapai tujuan tertentu dengan berhasil serta melakukan kendali terhadap keadaan-keadaan disekitarnya demi mencapai hasil tersebut.

Individu dengan efikasi diri akan kemampuan yang dimiliki dalam menghadapi dan menangani situasi perubahan serta memfungsikan dirinya lebih baik terhadap pekerjaan yang dijalankan meskipun terjadi berbagai tuntutan yang berasal dari perubahan organisasi tersebut (Wanberg \& Banas, 2000). Semakin tinggi efikasi seseorang maka semakin besar kepercayaan diri terhadap kemampuannya untuk berhasil dalam suatu tugas (Robbins, 2001). Efikasi diri yang tinggi diyakini mampu mempengaruhi munculnya motivasi dalam diri karyawan untuk selalu memperbaiki cara kerjanya.

Phillips dan Gully (1997) juga berpendapat bahwa individu dengan efikasi diri yang tinggi memiliki kecenderungan berusaha secara maksimal untuk mengantisipasi tantangan yang timbul dalam penyelesaian tugas sehingga memiliki keyakinan untuk mencapai tingkat kinerja tertentu. Myers (1999) menyatakan bahwa individu yang mempunyai tingkat efikasi diri yang tinggi akan memperlihatkan sikap yang lebih gigih, tidak cemas dan tidak merasa tertekan dalam menghadapi suatu tugas serta mempunyai motivasi yang tinggi.

Penelitian tentang aspek-aspek kepribadian dan SWB tersebut di atas menunjukkan bahwa faktor optimisme dan efikasi diri memberi pengaruh kuat terhadap SWB. Optimisme dan efikasi diri menjadi penentu keberhasilan tingginya SWB dan menjadi karakter kuat yang harus dipunyai perempuan pemimpin. Perempuan pemimpin akan meningkat kebahagiaan subjektifnya jika mempunyai faktor-faktor optimisme dan efikasi diri yang tinggi.

Berdasarkan uraian di atas dan latar belakang permasalahan maka permasalahan penelitian ini yakni bagaimanakah Hubungan optimisme dan efikasi diri terhadap SWB perempuan pemimpin?

\section{A. Hipotesis}


Hipotesis yang diajukan dalam penelitian ini adalah ada hubungan positif antara optimism dan efikasi diri secara bersama-sama maupun sendiri-sendiri terhadap SWB. Semakin tinggi optimism maka semakin tinggi pula efikasi diri terhadap SWB pada perempuan pemimpin.

\section{B. Tujuan}

Tujuan umum penelitian ini adalah menguji faktor-faktor optimisme dan efikasi diri terhadap SWB pada perempuan pemimpin.

Tujuan khusus penelitian ini adalah

1. Menguji secara empiris hubungan optimisme terhadap SWB perempuan pemimpin.

2. Menguji secara empiris hubungan efikasi diri terhadap SWB perempuan pemimpin.

\section{Manfaat}

Secara teoritis penelitian ini diharapkan dapat memberi masukan pengetahuan bagi studi perempuan hubungan optimism dan efikasi diri terhadap SWB.

Manfaat praktis yang diperolah antara lain:

a. Memberikan masukan pada penerapan bimbingan dan konseling pada karyawan perempuan yang menjadi pimpinan untuk meningkatkan SWB.

b. Menjadi informasi dan pengetahuan bagi perempuan bekerja, stake holder, pemerintah dan masyarakat tentang faktor-faktor yang perlu dikembangkan dan dihindari dalam kaitannya dengan SWB perempuan pemimpin.

\section{Dasar Teori}

Penelitian-penelitian tentang SWB secara umum terbagi tiga pendekatan untuk menjawab faktor-faktor apa yang membuat orang bahagia.

\section{Teori Bottom-up}

Menurut teori bottom-up, SWB hanya sebagai akumulasi kegembiraan yang kecil. Saat seseorang menilai apakah kehidupannya bahagia atau tidak, beberapa kalkulasi mental digunakan untuk menjumlah kegembiraan-kegembiraan dan penderitaanpenderitaan yang pernah dialami (Diener, dkk. 2001). Pendekatan bottom-up bermula dari pendapat Wilson bahwa ada kebutuhan-kebutuhan manusia yang bersifat mendasar dan umum, bila kebutuhan-kebutuhan tersebut terpenuhi, maka dia akan berbahagia (Diener, 
2000).

Faktor-faktor bottom-up yang mempengaruhi kebahagiaan subjektif adalah peristiwa-peristiwa luar, situasi, dan pengaruh demografis. Faktor-faktor luar yang pernah diteliti dan dapat meningkatkan kebahagiaan subjektif walaupun dalam jumlah sedikit adalah kekayaan, uang, dan tingkat sosial ekonomi tidak berpengaruh secara signifikan (Csikszentmihalyi, 1999), kesehatan (Contrada, Gonyal, Cather, Rafalson, Idler, \& Krause, 2004), penghasilan, kesehatan, dan hubungan sosial (Diener \& Suh, 1998), prestasi belajar (Crocker, Quinn, Karpinski, \& Chase, 2003), dan penampilan fisik (Diener, Suh, Lucas, \& Smith, 1999).

Pada awalnya banyak negara berpegangan bahwa kebahagiaan subjektif akan meningkat dengan meningkatnya pendapatan (materi) yang membuat banyak negara melakukan upaya keras untuk meningkatkan pendapatan negara. Namun hasil penelitian tidak mendukung hipotesa tersebut. Orang Amerika sekarang memperoleh dolar dua kali lipat dibandingkan tahun 1957 namun individu yang menyatakan sangat bahagia ternyata turun, dari 35\% ke 29\%. Depresi meningkat menjadi 10 kali lipat, bunuh diri di kalangan remaja menjadi tiga kali lipat yang menunjukkan bahwa tingginya pendapatan tidak selalu diikuti dengan tingkat kebahagiaan (Myers, 2000).

Penelitian lintas Negara yang dilakukan Diener dan Biswas-Diener (2002) mendukung terori bottom up yang menyatakan bahwa orang-orang yang di negara lebih miskin melaporkan tingkat kebahagiaan yang rendah. Hal ini mengartikan faktor lingkungan luar berpengaruh pada kebahagiaan. Penelitian terhadap remaja, yang miskin, kelas menengah atas dan kelas atas menunjukkan bahwa mereka yang miskin menunjukkan kebahagiaan subjektif yang tinggi dengan melakukan pengukuran beberapa kali dalam sehari selama tiga tahun (Csikszentmihalyi, 1999).

Orang-orang yang sangat kaya (100 orang yang terkaya di Amerika) yang di survei majalah Forbes, ternyata hanya sedikit lebih tinggi kebahagiaan subjektifnya dibandingkan dengan rata-rata orang Amerika. Mereka yang meningkat penghasilannya lebih dari periode 10 tahun, ternyata tidak lebih bahagia daripada yang penghasilannya tetap (Argyle, 2001). Diener dan Suh (I997) juga berpendapat bahwa uang dan kondisi kehidupan berdampak pada kepuasan hidup akan tetapi pengaruh tcrscbut tidak selalu kuat. Mereka mencontohkan bahwa indikator-obyektif (gabungan dari pendapatan, kesehatan, dan sebagainya) untuk negara Austria adalah 71, Nigeria hanya 30 tetapi kepuasan hidup kedua negara tersebut hanya terpaut kecil. 
Hal ini dapat disimpulkan bahwa dengan teori bottom up dan hasil-hasil penelitian menunjukkan bahwa peningkatan penghasilan dalam taraf tertentu mampu meningkatkan kebahagiaan subjektif manusia namun pada ambang batas tersebut apabila telah terlampaui maka pengaruh penghasilan terhadap kebahagiaan cenderung menurun.

\section{Teori Top-down}

Penelitian pada tahun-tahun belakangan inii mulai beralih mengeksplorasi daerah dalam diri manusia tersebut misalnya nilai-nilai hidup, tujuan dan kepribadian individu (Diener \& Diener, 2003). Hal ini yang dikenal dengan teori top down. Diener dan Scollon (2003) menjelaskan teori top-down yaitu seseorang menikmati kesenangan sebab dia bahagia, bukan sebaliknya. Struktur dalam diri manusia seperti nilai hidup, faktor genetik, temperamen dan kepribadian menyeluruh dianggap mempengaruhi cara orang bereaksi terhadap suatu peristiwa. Hal-hal yang ada dalam diri seseorang yang menentukan bagaimana memandang suatu peristiwa dan lingkungan. Contohnya individu yang optimis, riang mungkin akan menafsirkan sejumlah besar peristiwa sebagai sesuatu yang positif (Lucas \& Baird, 2004).

Menurut teori top down faktor-faktor yang berpengaruh terhadap kebahagiaan adalah kepribadian Lima Faktor, optimis, dan harga diri. Teori top down didukung penelitianpenelitian kepribadian, sikap dan persepsi diri yang mempunyai hubungan kuat pada kebahagiaan (DeNeve \& Cooper, 1998; Diener \& Lucas, 1999).

Kepribadian seseorang adalah gambaran penting yang bersifat stabil dan kepribadian yang bersifat ciri (trait) diantaranya mempunyai hubungan kuat terhadap kebahagiaan. Menurut Veenhoven (1994), kebahagiaan subjektif dapat berubah dan dipengaruhi oleh situasi. Hal ini didukung oleh bukti-bukti yang mendukung penelitian Veenhoven..

Ryan dan Deci (2001) menyatakan bahwa kebahagiaan subjektif tidak tergantung pada keberuntungan atau sebab-sebab luar namun lebih dipengaruhi oleh pikiran, keyakinan, dan kepribadian, termasuk di dalamnya agama yang telah terinternalisasi.

Teori top-down menunjukkan bahwa faktor internal antara lain faktor kepribadian pada individu memberi pengaruh kuat untuk dapat meningkatkan SWB.

\section{Metode}

Penelitian ini menggunakan metode penelitian kuantitatif.

Variabel dalam penelitian ini adalah:

1. Variabel tergantung : SWB 
2. Variabel bebas : a. Optimisme

b. Efikasi diri

\section{A. Subjek Penelitian}

Subjek dalam penelitian ini memiliki kriteria sebagai berikut:

a. Perempuan pekerja yang menjadi pemimpin dalam suatu unit kerja yang tinggal di Yogyakarta. Pemimpin yang dimaksud dalam subjek penelitian ini adalah Pegawai Negeri Sipil dan Staf Pengajar di Perguruan Tinggi yang menjadi pejabat di Fakultas.

b. Karakteristik organisasi yaitu bidang pendidikan (antara lain Dekan, Ketua Jurusan, Kepala program studi dan lain-lain) dan bidang pemerintahan (antara lain Kepala Bidang, Kepala Unit, Kepala Seksi dan lain-lain).

c. Usia subjek penelitian berkisar dari usia 26 tahun sampai dengan 56 tahun dengan pendidikan terendah SMU dan tertinggi S2.

Berdasarkan ciri subjek penelitian maka dilakukan pengambilan sampel dengan cara purposive sampling. Purposive sampling adalah pemilihan sekelompok subjek didasarkan atas ciri-ciri ata sifat-sifat tertentu yang dipandang mempunyai sangkut paut yang erat dengan ciri-ciri atau sifat-sifat populasi yang sudah diketahui sebelumnya (Hadi, 1997). Subjek penelitian berjumlah 87 orang.

\section{B. Metode Pengumpulan Data}

Metode pengumpulan data penelitian diperoleh dengan menggunakan skala. Skala ini menggunakan lima tingkat penilaian (skala Likert) yaitu nilai satu sampai lima, disusun dalam bentuk positif (favorable/ mendukung) dan negatif (unfavorable/tidak mendukung). Respon terhadap kepuasan hidup pada domain tertentu, tingkat seringnya mengalami emosi positif diperingkat berdasar skala 5 poin yakni Sangat Sesuai (SS), Sesuai (S), Antara Sesuai dan Tidak Sesuai (N), Tidak Sesuai (TS), Sangat Tidak Sesuai (STS).

Skala yang digunakan berjumlah tiga:

1. Skala Optimisme disusun peneliti yang dimodifikasi berdasar konsep Seligman (1995). Skala ini terdiri dari tiga dimensi yaitu gaya penjelasan yang berkaitan waktu (permanen), gaya penjelasan yang berkaitan dengan dimensi ruang lingkup (pervasif) dan gaya penjelasan yang berkaitan dengan sumber penyebab dari peristiwa yang dialaminya (personalisasi). Skala ini menggunakan lima tingkat penilaian (skala Likert) yaitu nilai satu sampai lima, disusun dalam bentuk positif (favorable/mendukung) dan negatif (unfavorable/tidak mendukung). 
2. Skala Efikasi Diri yang dibuat peneliti berdasar konsep Bandura (1994). Aspek efikasi diri ada tiga yaitu tingkat kesulitan tugas, luas bidang perilaku dan kekuatan individu. Skala ini menggunakan lima tingkat penilaian (skala Likert) yaitu nilai satu sampai lima, disusun dalam bentuk positif dan negatif.

3. Skala SWB yang disusun oleh peneliti berdasar konsep Diener (2004). Skala ini terdiri dari dua dimensi yaitu kepuasan hidup dan afeksi positif. Dimensi kepuasan hidup memiliki butir soal lebih banyak (21 butir soal) dibanding dimensi afeksi positif (10 butir soal) karena mengukur kepuasan hidup sehari-hari, hubungan dgn kelompok, lingkungan, kesehatan dan keberhasilan.

Skala-skala tersebut sudah dilakukan uji coba dengan hasil koefisien $\alpha>0,4$.

\section{Analisis Data}

Analisis data menggunakan analisis berdasar teknik statistik regresi ganda dengan dua prediktor untuk mengetahui sumbangan kedua variable bebas yakni optimsme dan efikasi diri terhadap variable tergantung yakni SWB. Setelah itu dilanjutkan dengan korelasi parsial untuk mengetahui korelasi antara salah satu variable bebas dengan variable tergantung yang lebih bersih dengan cara mengontrol pengaruh variable bebas lainnya. Analisis data menggunakan program SPSS.

\section{Hasil dan Pembahasan}

Data yang terkumpul dianalisis dengan analisis regresi dengan menggunakan fasilitas program SPSS.

\section{A. Hasil}

Hasil analisis diperoleh sebagai berikut:

a. Hasil analisis regresi menunjukkan terdapat hubungan yangi positif antara optimism dan efikasi diri terhadap SWB pada perempuan pemimpin, sehingga hipotesis yang diajukan dalam penelitian ini diterima secara signifikan dengan harga $R=0.577(\mathrm{p}<0.01)$ dan $F=20.984(\mathrm{p}<0.01)$.

b. Hubungan antara optimism terhadap SWB pada perempuan pemimpin diperolah dengan $\mathrm{p}=0.001$ dan $\mathrm{r}=0.561$. Dapat disimpulkan bahwa ada hubungan antara optimism terhadap SWB pada perempuan pemimpin.

c. Hubungan antara efikasi diri terhadap SWB pada perempuan pemimpin diperoleh dengan $\mathrm{p}=0.135$ dan $\mathrm{r}=0.486$. Dapat disimpulkan bahwa tidak ada hubungan 
antara efikasi diri terhadap SWB pada perempuan pemimpin.

d. Koefisien determinasi ke tiga variable bebas secara bersamaan adalah $\mathrm{R}^{2}=33.30$ $\%$. Harga tersebut mengandung arti bahwa secara bersama-sama variable optimism dan efikasi diri menentukan tinggi rendahnya SWB sebesar $33.30 \%$, sedangkan sisanya $(66.70 \%)$ ditentukan oleh variable-variabel lain yang tidak dilibatkan dalam penelitian ini.

e. Berdasarkan 2 (dua) variabel Optimisme dan efikasi diri maka hanya variabel optimisme yang terbukti mempunyai hubungan positif terhadap SWB dengan memberi sumbangan efektif sebesar 0.561 .

Tabel 1 Model Summary

\begin{tabular}{|l|r|r|r|r|}
\hline Model & \multicolumn{1}{|c|}{$\mathrm{R}$} & R Square & \multicolumn{1}{c|}{$\begin{array}{c}\text { Adjusted R } \\
\text { Square }\end{array}$} & $\begin{array}{r}\text { Std. Error of } \\
\text { the Estimate }\end{array}$ \\
\hline 1 &, $577^{\mathrm{a}}$ &, 333 &, 317 & 5,66314 \\
\hline
\end{tabular}

a. Predictors: (Constant), EFIK, OPT

Tabel 2 ANOVA ${ }^{\mathrm{a}}$

\begin{tabular}{|rl|r|r|r|r|r|}
\hline \multicolumn{2}{|l|}{ Model } & \multicolumn{1}{|l|}{$\begin{array}{l}\text { Sum of } \\
\text { Squares }\end{array}$} & df & Mean Square & F & \multicolumn{1}{c|}{ Sig. } \\
\hline 1 & Regression & 1345,951 & 2 & 672,975 & 20,984 &, $000^{\mathrm{b}}$ \\
& Residual & 2693,980 & 84 & 32,071 & & \\
& Total & 4039,931 & 86 & & & \\
\hline
\end{tabular}

a. Dependent Variable: SWB

b. Predictors: (Constant), EFIK, OPT

Tabel 3 Coefficients ${ }^{\mathrm{a}}$

\begin{tabular}{|c|c|c|c|c|c|c|c|}
\hline \multirow{2}{*}{\multicolumn{2}{|c|}{ Model }} & \multicolumn{2}{|c|}{$\begin{array}{c}\text { Unstandardized } \\
\text { Coefficients }\end{array}$} & \multirow{2}{*}{$\begin{array}{c}\begin{array}{c}\text { Standardized } \\
\text { Coefficients }\end{array} \\
\text { Beta }\end{array}$} & \multirow[b]{2}{*}{$\mathrm{t}$} & \multirow[b]{2}{*}{ Sig. } & \\
\hline & & B & Std. Error & & & & $\mathrm{Ze}$ \\
\hline 1 & (Constant) & 43,330 & 7,119 & & 6,087 &, 000 & \\
\hline & OPT &, 401 &, 115 & ,432 & 3,493 & ,001 & \\
\hline
\end{tabular}




\begin{tabular}{|c|c|c|c|c|c|c|}
\hline EFIK & 113, & ,075 & 187, & 1,511 & , 135 & ,486 \\
\hline
\end{tabular}

a. Dependent Variable: SWB

\section{B. Pembahasan}

Hasil analisis regresi menunjukkan bahwa ada hubungan optimisme dan efikasi diri secara bersama-sama terhadap SWB perempuan pemimpin. Sumbangan total variabel terhadap SWB sebesar $33.30 \%$ yang dihasilkan dari variabel optimisme dan efikasi diri.

Perempuan yang berpandangan penuh optimis akan menjadi dasar bagi individu tersebut untuk berfikir positif bahwa peluang, orang-orang di sekitarnya, masa depan, dan kesukaran hari ini akan menjadi baik atau lebih baik di hari yang akan datang, sehingga menjadi kekuatan untuk tampil terbaik ketika dihadapkan pada tugas - tugas penting dalam kehidupannya.

Rasa optimisme yang tinggi akan mampu beradaptasi terhadap stressor dalam mencapai tujuan organisasi dan kehidupan, tidak menyalahkan diri ketika mengalami kegagalan, lebih jeli melihat peluang kehidupan. Rasa optimis tersebut secara langsung akan menjadikan perempuan pemimpin tersebut terlihat bahagia dan dapat menyelesaikan konflik-konflik yang muncul antara pekerjaan dan keluarga. Konflik yang muncul baik dari organisasi atau keluarga dapat dikelola dengan baik dengan kemampuan adaptasi karena keyakinan penuh selalu ada jalan keluar dari setiap masalah yang muncul (Situmorang, 2012).

Keyakinan positif dan kekuatan teguh atas segala sesuatu yang dialami tersebut akan memudahkan individu untuk mencapai target-target yang telah ditentukan sebelumnya. Rasa optimis yang dipunyai individu yang berupa keyakinan kuat dan harapan pada masa depan secara bersamaan juga menumbuhkan efikasi diri yakni mampu menghadapi tantangan yang diperlukan.

Efikasi diri merupakan kekuatan untuk menuju sukses dan merupakan determinan penting dalam menentukan apakah individu mau melakukan perubahan yang diperlukan. Efikasi diri tinggi menimbulkan keyakinan dan menunjukkan hubungan langsung dan hubungan tidak langsung pada kebahagiaan. Individu dengan efikasi diri mempunyai kemampuan untuk berperilaku sehat, punya pertahanan diri dalam menghadapi godaan dan lebih cepat pulih bila terjadi kemunduran atau kegagalan.

Individu dengan efikasi diri yang tinggi cenderung menjadi lebih puas dengan pekerjaannya secara keseluruhan dan menghasilkan performansi tinggi pula sedangkan 
kepuasan kerja tinggi merupakan salah satu faktor timbulnya kebahagiaan. Keyakinan akan kemampuan dalam menghadapi tantangan yang timbul dari rasa optimis diikuti dengan keyakinan bahwa Tuhan akan memberi sesuai dengan usahanya menjelma pada kemampuan kuat untuk dapat menghadapi tugas, mengatasi rintngan dan melakukan tindakan yang diperlukan (Situmorang, 2012).

Individu yang memiliki perasaan efikasi diri yang tinggi dalam situasi yang penuh tekanan akan memiliki keadaan fisik dan psikologis yang lebih baik (Brehm \& Kassin, 1990). Keyakinan akan kemampuan dirinya untuk dapat mencapai tujuan sesuai harapan akan membuatnya menikmati hidup, selalu gembira dan menunjukkan perilaku sehat yang cenderung akan menunjukkan emosi positif dan rasa bahagia.

Hal ini membuktikan penjelasan hasil penelitian berdasar pendekatan top down yakni individu dapat menikmati kebahagiaan karena dia mampu bereaksi secara positif terhadap suatu peristiwa (Diener \& Scollon, 2003). Diener dan Larsen (1984) menemukan bahwa pengaruh faktor kepribadian terhadap kebahagiaan subjektif lebih besar dibandingkan faktor eksternal.

SWB menurut pendekatan Top down lebih karena variabel internal pola fikir keyakinan dan kepribadian dibanding variabel eksternal. Hasil penelitian menunjukkan hasil yang mendukung dengan penelitian sebelumnya dan berdasar teori top down bahwa sifat pribadi dalam penelitian ini yakni optimisme dan efikasi diri mempunyai hubungan dengan kebahagiaan subjektif.

Namun efikasi diri secara partial tidk mempunyai hubungan dengan SWB. Variabel optimisme yang menunjukkan hubungan signifikan terhadap SWB perempuan pemimpin. Hal ini jika dilihat korelasi lugas antara kedua variable tersebut menunjukkan hubungan positif, tetapi jika dilakukan pengontrolan variable bebas lain ternyata hubungannya tidak signifikan. Hal tersebut dapat dijelaskan karena adanya multikolinieritas antara sesama variabel bebas cukup tinggi, sehingga jika variabel optimisme dihadirkan bersama-sama dengan efikasi diri terhadap SWB mempunyai peran yang penting. Hal tersebut tidak berlaku jika variabel efikasi diri dikorelasikan secara lugas dengan variabel SWB. Berdasarkan hasil korelasi lugas diperoleh korelasi sebesar $\mathrm{r}$ $=0.486$. Berdasarkan hasill tersebut dapat dikatakan bahwa jika efikasi diri dikorelasikan secara lugas dengan SWB, maka peranannya juga cukup besar. Perempuan pemimpin yang mempunyai penilaian bahwa efikasi diri akan memberi hasil yang positif akan menunjukkan SWB tinggi pada organisasi.

Selain itu jika dilihat dari skala efikasi diri dengan aspek tingkat kesulitan tugas, luas 
bidang tugas dan kekuatan individu berisi item yang menunjukkan skala efikasi diri secara umum, belum mencerminkan efikasi diri secara khusus pada perempuan pemimpin.

\section{Simpulan dan Saran}

\section{A. Simpulan}

a. Simpulan penelitian menunjukkan terdapat hubungan yangi positif antara optimism dan efikasi diri terhadap SWB pada perempuan pemimpin. Perempuan pemimpin dengan multi peran sebagai pimpinan di organisasi dan peran sebagai ibu dan isteri dalam keluarga mempunyai SWB tinggi jika didukung oleh rasa optimisme dan efikasi diri dalam menyikapi hal-hal yang dialami perempuan pemimpin dengan pendekatan fikiran positif.

b. Penelitian ini menunjukkan secara empiris ada hubungan antara optimisme terhadap SWB perempuan pemimpin. Individu akan merasakan kebahagiaan tinggi jika memiliki optimisme yang kuat dan dalam penelitian ini rasa optimisme memberi pengaruh yang paling besar terhadap kebahagiaan subjektif perempuan pemimpin.

c. Penelitian ini menunjukkan secara empiris tidak ada pengaruh efikasi diri terhadap SWB perempuan pemimpin. Faktor kuat atau rendahnya efikasi diri yang dimiliki subjek penelitian tidak berpengaruh pada kebahagiaannya dimana keyakinan diri untuk mencapai keberhasilan pada penelitian ini tidak dapat menentukan bahagia atau tidaknya individu.

\section{B. Saran}

a. SWB perempuan pemimpin dapat ditingkatkan dengan peningkatan optimisme yang merupakan faktor yang memiliki sumbangan paling kuat terhadap SWB. Intervensi yang berbasis pada peningkatan gaya berfikir optimis disarankan untuk diterapkan dalam organisasi untuk meningkatkan SWB perempuan pemimpin. Rasa optimisme yang tinggi menjadi acuan karakteristik kepribadian pada perempuan yang menjadi pimpinan dalam organisasi.

b. Bagi para peneliti dapat mengembangkan model SWB perempuan pemimpin pada variabel kepribadian selain optimisme dan efikasi diri. 


\section{DAFTAR PUSTAKA}

Argyle, M. (2001). The psychology of happiness. New York: Taylor \& Francis.

Bandura, A. (1994). Social Cognitive Theory and exercise of control over HIV infection. In R. DiClemente and J. Peterson (eds.), Preventing AIDS: Theories and methods of behavioral interventions (pp. 25-59). New York: Plenum.

Bandura, A. (1997). Self Efficacy: The Exercise of Control. New York: Freeman

Barette, J. (2006). Work/Family Balance: What Do We Really Know?. Canada: Vanier Institute of The Family.

Bass (1990) Bass, B.M. (1990). Bass \& Stogdill's: Handbook of Leadership, Theory, Research \& Managerial Application. ( $3^{\text {rd }}$ Ed.). New York: The Free Press.

Brehm, S.S. \& Kasssin, S. M. (1990). Social Psychology. Boston: Houghton Mifflin Company.

Contrada, R. J., Gonyal, T. M., Cather, C., Rafalson, L., Idler, E. L., \& Krause, T.J. (2004a). Psychosocial factors in outcomes of heart surgery: The impact of religious involvement and depressive symptoms. Journal of Health Psychology, 23, 227-238.

Crocker, J., Quinn, D. M., Karpinski, A., \& Chase, S. K. (2003). When grades determine self worth: Consequences of contingent welf worth for male and female engineering and psychology majors. Journal of Personality and Social Psychology, 85, 507-516. dan penampilan fisik (Diener, Suh, Lucas, \& Smith, 1999).

Csikszentmihalyi, M. (1999). If we are so rich, why aren't we happy? American Pshycologist, 54, 821-827.

Danner, D. D., Snowdon, D. A., \& Friesen, W. V. (2001). Positive emotions in early life and longevity: Findings from the nun study. Journal of Personality and Social Psychology, 80, 804-813.

DeNeve, K. M., \& Cooper, H. (1998). The happy personality: A metaanalysis of 137 personality traits and subjective well-being. Psychological Bulletin, 124, 197-229.

Diener, E. (1999). Introduction to the special section on the structure of emotion. Journal of Personality and Social Psychology, 76, 803-804.

Diener, E. (2000). Subjective Well-Being: The science of happiness, and a proposal for a national index. American Psychologist, 55, 34-43.

Diener, E. (2002). Learning to publish Review of the book Guide to publishing in psychology journals. Contemporary Psychology: APA Review of Books, 47, 212213.

Diener, E. (2004). The Non-Obvious Social Psychology of Happiness. Journal of 
Psychological Inquiry, 62.

Diener, E., \& Biswas-Diener, R. (2002). Will money increase subjective well-being? A literature review and guide to needed research. Social Indicators Research, 57, 119169.An Interdisciplinary Periodical on Subjective Well-Being, 1, 41-78.

Diener, E,. \& Diener, R.B. (2003). Finding on Kesejahteraan subjektifand Their Implications for Empowerment. Paper dipresentasikan pada Workshop Measuring Empowerment. Cross Dicilinary Perspective. Washington DC: World Bank, February 4 dan 5, 2003.

Diener, E., \& Larsen, R. J. (1984). Temporal Stability and Crosssituational Consistency of Affective, Behavioral, and Cognitive Responses. Journal of Personality and Social Psychology, 47,580-592.

Diener, E., \& Lucas, R. (1999). Personality and subjective we1l-being.In D. Kahneman, E. Diener, and N. Schwarz (Eds.), Well-being: The foundations of Hedonic Psychology (pp. 213-229). New York: Russel Sage Foundation.

Diener, E., \& Lucas, R. (2000). Explaining differences in societal levels of happiness: Relative standards, need fulfillment, culture, and evaluation theory. Journal of Happiness Studies, 1, 41-78.

Diener, E. \& Scollon, C. (2003). Subjective well being is desirable, but not the summon bonum. Paper delivered at the University of Minnesota interdisciplinary Workshop on Well Being, Minneapolis; October 23-25.

Diener, E., Oishi, S., \& Lucas, R. E. (2003). Personality, culture, and subjective wellbeing: Emotional and cognitive evaluations of life. Annual Review of Psychology, $54,403-425$.

Diener, E., Wirtz, D., \& Oishi, S. (2001). End effects of rated life quality: The James Dean Effect. Psychological Science, 12, 124-128.

Diener, E. \& Suh, E. (1997). Measuring Quality Oflife: Economic, social and subjective indicators. Social Indicators Research, 40, 189-216.

Diener, E., \& Suh, E. (1998). Subjective Well-Being and Age: An international analysis. Annual Review of Gerontology and Geriatrics. 17,304-324.

Feasel, K. E. (1995). Mediating the relations between goals and subjective well-being: Global and domain-specific variants of self-efficacy. Unpublished master's thesis. University of Illinois.

Hadi, S, (1997), Metodologi Research, untuk Penulisan Paper, Skripsi, Thesis,. Disertasi, Yogyakarta: Andi Offiset

Judge, T.A. Thoreson, C.J. Bono, J.E. \& Patton, G.K. (2001). The job satisfaction-job performance relationship:a qualitative and quantitative review" ,Psycologycal Bulletin, 127, 376-407. 
Koivumaa-Honkanen, H., Koskenvuo, M., Honkanen, R. J., Viinamaki, H., Heikkilae, K., \& Kaprio, J. (2004). Life dissatisfaction and subsequent work disability in an 11 years follow-up. Psychological Medicine,34, 221-228.

Lounsbury, J.W., James, M.L., Eric, D.S., Lucy, W.G., Adam, W.D., \& Frances, L.H. (2003). An Investigation of Personality Traits in Relation to Career Satisfaction. Journal of Career Assessment, 11, 287 - 307.

Lucas, R. E., \& Baird, B. M. (2004). Extraversion and emotional reactivity. Journal Personality and Social Psychology, 86, 473-485.

Lucas, R. E., Diener, E., \& Suh, E. (1996). Discriminant validity of well-being measures. Journal of Personality and Social Psychology, 3, 616-628.

Lyubomirsky, S., Kasri, F., \& Chang, O. (2002). Ruminative style and delay of presentation of breast cancer symptoms. Manuscript in preparation.

Mastekaasa, A. (1994). Marital status, distress, and well-being: An international comparison. Journal of Comparative Family Studies, 25, 183-205.

Myers, D. G. (1999). Close relationships and quality of life. In D. Kahneman, E. Diener, \& N. Schwarz (Eds.), Well-being: The foundations of hedonic psychology (374-391). New York: Russell Sage Foundation.

Myers. D.G. (2000). Funds, Friends, and Faith of Happy People. American Psychologist. 55, 56-57.

Phillips, J. M., \& Gully, S. M. (1997). The role of goal orientation, ability, need for achievement, and locus of control in the self-efficacy and goal setting process. Journal of Applied Psychology, 82, 792-802.

Rakhmat, J. (2006). Meraih Kebahagiaan.. Bandung: Sibiosa rekatama Media.

Robbins, S.P. (2001). Organizational behaviour: Concept, controversies and applications (9th Ed). New Jersey: Prentice Hall Inc.

Ryan, R.M. \& Deci, E.L. (2001). On Happiness and Human Potentials: A review of Research on Hedonic and Eudaimonic WellBeing. Annual Review Psychology, 52, 141-166.

Scheier, M. F., \& Carver, C. S. (1993). On the power of positive thinking: The benefits of being optimistic. Current Directions in Psychological Science, 2, 26-30.

Seligman, M.E. P. (1995). The Optimistic Child. New York: Houghton Mifflin Company.

Seligman, M. E. P. (2003). The Past and Future of Positive Psychology. In C.L. Keyes \& J. Haidt (Eds.). Flow Positive Psychology and The Life Well-Lived (pp. xi - xx). Washington, DC: American Psychological Association. 
Situmorang, N. Z. (2012). Pengaruh religisitas, optimisme, efikasi diri dan keseimbangan peran kerja keluarga terhadap kebahagiaan subjektif perempuan pemimpin. Disertasi tidak dipublikasikan. Yogyakarta: Universitas Gadjah Mada.

Veenhoven, R., \& Team (1994). World database of happiness: Correlates of happiness. Rotterdam: Erasmus University.

Wanberg, C. R. \& Banas, J. T. (2000). Predictors and outcomes of opened to change in reorganizing workplace. Journal of Applied Psychology, 85, 132-142. 